\title{
Physical Characteristics and Proximate Composition of Three Commercial Shrunken 2 Varieties of Sweet Corn in the Philippines as Influenced by Harvest Maturity
}

\author{
Gemaima C. Evangelista ${ }^{1}$, Angelina dR Felix ${ }^{2}$ \\ ${ }^{1}$ University of the Philippines, \\ Los Baños Laguna, Philippines \\ Email: gcevangelistal [AT] up.edu.ph \\ ${ }^{2}$ University of the Philippines, \\ Los Baños Laguna, Philippines \\ Email:adfelix2 [AT] up.edu.ph
}

\begin{abstract}
The physical and proximate characteristics of three commercial varieties of shrunken 2 sweet corn as affected by harvest maturities (18, 20 and 22 days after 100\% silking) were evaluated. As sweet corn, there was a significant increase in length in SC1 and SC2. On the other hand all varieties ear diameter increased with maturity. The three varieties have significant differences in ear length and diameter. Lightness of kernels was not affected by maturity and varietal differences. Increasing $a *$ and $b *$ values suggested that the kernels became more red and yellow as they mature on the plant due to carotenogenesis. The $a^{*}$ and $b *$ values of SC1 and SC2 were significantly affected by maturity while SC3 was not. In terms of chroma, only SC2 was significantly affected by harvest maturity, with an increased in color vividness as it matured in the plant. While hue values of the three varieties were not affected by harvest maturity. SC1 and SC2 kernel percentage moisture decreased significantly as sweet corn matures in the plant. Percentage ash content was not significantly affected by harvest maturity. On the other harvest maturity affected SC1 and SC2 percentage protein, but not their fiber content. The percentage fat and nitrogen free extract of SC1 kernel decreased as the plant matures. Mean energy content was significantly different with harvest maturity in all three varieties at a P value $<0.01$ (SC1 and SC2) and P = 0.05 (SC3). Harvest maturity affected the physical and proximate composition of the three commercial varieties of shrunken 2 sweet corn in the Philippines.
\end{abstract}

Keywords - shrunken 2 sweet corn, harvest maturities, proximate composition, physical characteristics

\section{INTRODUCTION}

Corn is considered as the second staple food next to rice and the second most important crop in the Philippines. Furthermore, production of s pecial types of corn such as glutinous corn, popcorn, high ly sine/tryptophan corn, and sweet corn is found to secure source of livelihood to farmers. Compared to growing corn for grain, s weet corn is easier to grow, less predisposed to ins ect infestation, labor-saving and more profitable (Gutierrezet al., 2003). Corn can also be processed into high valued products, such as cornstarch, corn syrups, corn oil, gluten and snack foods. Corn plant can be subdivided into variou s groups differing in character of the seeds. These group types are dent, flint, s weet, flour, popcorn, waxy and pod corn. These groups represent an artificial clas sification that is not indicative of natural relationships. Amid different corn groups, sweet corn (Zea mays L.) has become of importance (Jugenheimer, 1976). Sweet corn is valued due to its consumer acceptability and nutritional benefits. Corn is known to be a good source of vitamin E and A and unsaturated fats that are needed to attain a healthy lifes tyle. Fresh s weet corn arrived at the market for consumer use (Szymanek et al, 2006).

Corn can be classified in seven agricultural groups which is an artificial classification that is not indicative of any natural relationships. These are dent, flint, popcorn, flour, waxy and sweet. Sweet corn (Zea mays L.) is a variety of com with high sugar content. Sugar is converted into starch during the maturation process. Sweet corn must be consumed fresh as poor storage can result to tough and starchy s weet corn kernels. Sweet corn is now als o being marketed as a new age super diet for health conscious individuals (Johari and Kaushik, 2016).

Both qualitative and quantitative losses in vegetables can have a great impact on their acceptability. Those are the reas ons why harvesting and handling, which should be done carefully, are important in agricultural operations to maintain 
quality vegetables and lessen damage to crops. Quality of vegetables is determined by various physicochemical parameters such as color, shape, size, glos s, firmnes s, total soluble solids (TSS), pH, dry matter (DM), and acidity which can involve laborious laboratory techniques that are destructive in nature and in need of trained personnel.

As sugar in sweet corn is readily converted to starch during the maturation process and upon harvest, it must be consumed or process immediately as it cannot withstand poor or long period of storage conditions. Determining physicochemical characteris tics will allow further development of post-harvest timing and methods while determining proximate compositions can be used in value additions of sweet corn processing. Nowadays, many developed countries have emerged as a major hub of agricultural export for many developing countries thus stringent quality evaluation methods must be developed and maintained to attain acceptable quality level to end users or consumers.

The objectives of the research is to determine differences in proximate composition and physicochemical characteristics of existing commercial varieties of shrunken-2 sweetcorn in the Philippines as affected by harvest maturity.

\section{MATERIALS AND METHODS}

\subsection{Sample preparation and collection}

In this study, seeds were sown on experimental fields of Hortanova Research Center. Seeds were sown on July 11, 2016 and ten-day old seedlings were planted on their designated plots with 0.75 meter spacing between bed centers and $0.50 \mathrm{~m}$ between blocks. Plants were enriched with the equivalent of complete, ammonium sulfate, potash, and calcium nitrate. Furrow was the irrig ation used while hilling up and hand weeding was done. Sweet corns were hand harvested at three different maturities; eighteen (18), twenty (20) and twenty-two (22) days after 100\% silking (DAS). Husked sweet corn were evaluated in terms of cob diameter, length, mas s, color, and proximate composition.

\subsection{Determination of physicochemical characteristics and proximate composition}

The mass of sweet corn ( $\mathrm{g}$ ) was measured by u sing digital balance with the sensitivity of 0.01 .

Diameter $(\mathrm{D})(\mathrm{mm})$ and Length $(\mathrm{L})(\mathrm{cm})$ of s weetcorn were meas ured by using manual caliper (accuracy of 0.01$)$.

Chromatic properties, CIE-L*a*b* coordinated were meas ured using portable s pectrophotometer CAPSURE ${ }^{\mathrm{TM}}\left(\mathrm{RM}^{*}\right.$ 200). Three points (top, middle, bottom) at both sides were carried out for each ear. Color values were recorded as " $L$ " (0, black; 100, white), "a"' (-, greenness: +, redness), "b” (-, blueness: +, yellownes s). The chroma and hue angle values were computed using the formula:

$$
\begin{aligned}
& \text { Chroma }=\sqrt{ } \mathrm{a}^{2}+\mathrm{b}^{2} \\
& \text { Hue }=\tan ^{-1} \mathrm{~b} / \mathrm{a}
\end{aligned}
$$

Official methods of analysis of the AOAC $199516^{\text {th }}$ edition was used in proximate composition analy sis.

\subsection{Statistical Analysis}

Analysis was performed using R Statistical Package s oftware (R: 3.1.1 and R Studio: 1.0.44). The R Statis tical Package can be used for s tatis tical analy sis, simulation modeling and adv anced data analy sis. The data on physicochemical analysis and sensory evaluation were subjected to two factor Analy sis of Variance (ANOVA) and pairwise t-tests.

\section{RESULTS AND DISCUSSIONS}

\subsection{Physical properties of sweet corn}

Three commercial varieties of sweet corn belonging to shrunken2 (sh2) phenotype were used in this study namely: $\mathrm{SC} 1, \mathrm{SC} 2$ and SC3 to determine the effect of harvest maturity to physicochemical and proximate characteris tics. SC1 had a medium green husk color and bigger cylindrical cob. SC2 has the greenest husk and slimmer cob. It is well adapted to rainy seas on and has strong plant vig or that allow it to withstand fungal attacks. SC2 plant has a strong root systemthat tolerate heavy rains and wind. Lastly, SC3 is designed for Malaysia market and neighboring countries. It is known to be tolerant of both drought and rain. SC3 has a greener husk compared to SC1 (https://agrosifu.wordpress.com. 2014). 
Table 1: Phy sical characteristics of sweet corn as affected by harvest maturity

\begin{tabular}{|c|c|c|c|c|c|c|c|c|}
\hline Variety & $\begin{array}{c}\text { Harvest } \\
\text { Maturity } \\
\text { (days) }\end{array}$ & $\mathbf{L}^{*}$ & $\mathbf{a}^{*}$ & $\mathbf{b}^{*}$ & Chroma & Hue & Length (cm) & $\begin{array}{c}\text { Diameter } \\
\text { (mm) }\end{array}$ \\
\hline \multirow[t]{3}{*}{ SC1 } & 18 & 75.48 & $8.47^{\mathrm{a}^{* *}}$ & $52.57^{a * *}$ & 53.39 & 1.67 & $17.5^{\mathrm{a}^{*}}$ & $50.97^{\mathrm{a}^{*}}$ \\
\hline & 20 & 75.09 & $9.96^{\mathrm{b}^{* * *}}$ & $54.22^{a b^{* *}}$ & 55.24 & 1.35 & $18.67^{b^{*}}$ & $54.7^{\mathrm{b}^{\mathrm{*}}}$ \\
\hline & 22 & 75.52 & $11.31^{\mathrm{c} * *}$ & $56.15^{\mathrm{b} * *}$ & 56.10 & 1.48 & $19.99^{c^{*}}$ & $55.5^{\mathrm{b}^{*}}$ \\
\hline \multirow[t]{3}{*}{ SC2 } & 18 & 74.86 & $8.31^{\mathrm{b} * * *}$ & $51.17^{\mathrm{a}^{* * * *}}$ & $51.92^{\mathrm{a} * *}$ & 1.49 & $18.5^{\mathrm{a}^{*}}$ & $29.11^{\mathrm{a}^{*}}$ \\
\hline & 20 & 75.14 & $7.17^{\mathrm{a}^{* * * *}}$ & $50.62^{\mathrm{a}^{* * * *}}$ & $51.20^{\mathrm{a}^{* * *}}$ & 1.34 & $20.26^{\mathrm{b}^{*}}$ & $52.06^{\mathrm{b}^{*}}$ \\
\hline & 22 & 75.33 & $10.46^{\mathrm{c} * * *}$ & $54.83^{b^{* * * *}}$ & $55.88^{\mathrm{b} * *}$ & 1.36 & $20.24^{b^{*}}$ & $53.32^{\mathrm{b}^{*}}$ \\
\hline \multirow[t]{3}{*}{ SC3 } & 18 & 77.05 & 9.27 & 51.69 & 52.58 & 1.07 & 15.46 & $52.2^{\mathrm{a}^{* * * *}}$ \\
\hline & 20 & 76.24 & 8.65 & 54.64 & 55.47 & 1.17 & 16.56 & $51.32^{\mathrm{a}^{* * * *}}$ \\
\hline & 22 & 75.5 & 10.99 & 53.49 & 54.75 & 1.25 & 18.36 & $55.99^{\mathrm{c} * * *}$ \\
\hline
\end{tabular}

Numeric description of color using L*a* $\mathrm{b}^{*}$ CIELAB color space. $\mathrm{L}^{*}$ (lightness or darkness) ranges fromblack $(0)$ to white $(100) ; a^{*}$ color direction in red $\left(a^{*}>0\right)$ or green $\left(a^{*}<0\right)$; $b^{*}$ color direction in yellow $\left(b^{*}>0\right)$ or blue $\left(b^{*}<0\right)$. Chroma (s aturation or vividness) $=$ as chromaticity increases, a color becomes more vivid; as it decreases, a color becomes more dull. Hue (tint of color) $=$ an angular measurement in which $0=$ red and $90=$ yellow*Means having different letter in a column are significantly different at $\mathrm{P}<0.01 * *$ Means having different letter in a column are significantly different at $\mathrm{P}=0.01 * * *$ Means having different letter in a column are significantly different at $\mathrm{P}=0.05$

Ear length and diameter are quality factors being evaluated in sweet corn for marketing. According to Philippine National Standards on sweet corn, the three shrunken 2 varieties are classified under medium size in terms of length as it ranges from $15-20 \mathrm{~cm}$. SC1 and $\mathrm{SC} 2$ varieties are found to be affected by harvest maturity with $\mathrm{P}$ value $<0.01$. As the sweet corn matures there is an increased in length. Sweet corns harvested at 22 DAS were the longest cob regardless of variety. On the other hand SC3 ear leng th was not affected by harvest maturity. Ear leng th is significantly different among the three varieties at $\mathrm{P}$ value $<0.01$. The ear length of $\mathrm{SC} 1, \mathrm{SC} 2$ and $\mathrm{SC} 3$ are $18.71 \mathrm{~cm}, 19.67 \mathrm{~cm}$ and $16.79 \mathrm{~cm}$ respectively. $\mathrm{SC} 2$ has the longest earfollowed by SC1 and SC2.

Ear diameters of the three varieties are affected by harvest maturity, SC 1 and SC 2 at $\mathrm{P}$ value $<0.01$ while SC 3 at $\mathrm{P}$ value $=0.01$. Same with length, as the sweet corn matures there is an increase in diameter with thoseharvested at 22DAS having the highest diameter. This can be attributed to continuous maturation of corn cob prior to harvest. Ear diameter is significantly different among the three varieties at $\mathrm{P}$ value $<0.01$. SC1 was found to be of highest diameter measurement of $53.72 \mathrm{~cm}$ followed by SC3 and $\mathrm{SC} 2$ with $53.17 \mathrm{~cm}$ and $44.83 \mathrm{~cm}$ respectively.

Food color is known to be the first quality criteria evaluated by consumers. Color spaces are used to determine quantitative color. CIE L*a*b* color space is generally used in food color due to its uniform color distribution and closeness to human eye color perception. On the other hand, the problem with using this color space is that commercial color meters only measure dozen of square centimeters of food item and is not representative for most heterogeneous materials (Markovic et al.,n.d).

The chromatic properties examined in this study were lightness $\left(\mathrm{L}^{*}\right)$, redness $\left(\mathrm{a}^{*}\right)$, yellowness $\left(\mathrm{b}^{*}\right)$, chroma $\left(\mathrm{C}^{*}\right)$, and hue angle $\left(\mathrm{h}^{*}\right)$. The $\mathrm{L}^{*}$ values of the three varieties were not affected by harvest maturity. This suggested that lightness of kernels was not affected by harvest maturity and varietal differences. Similarly with the study doneby Alanet al. (2014), sweet corn studied for 2 different years showed that $L^{*}$ values were not significantly affected by varietal differences. The $\mathrm{a}^{*}$ value of CIELAB color system meas ures red and green coloration of the samples. This is found to be related to lycopene content of the vegetables or fruits being studied. Table 1 shows that $\mathrm{SC} 1$ and $\mathrm{SC} 2$ varieties a* values were significantly affected by harvest maturity with $P$ values of $<0.01$ and $=0.01$, respectively. In SC1 variety, a* values increased with harvest maturity. Harvest at 18DAS had the lowest value of 8.47 followed by harvest 20 and 22 DAS with 9.96 and 11.31, respectively. At 20 DAS, SC2 variety had the lowest $a^{*}$ value of 7.17 followed by 8.31 and 10.46 for 18 and 22 DAS, 
respectively. Increasing $a^{*}$ values suggest that the kernels become more red than green as it matures in the plant. This can be attributed to commencement of carotenogenesis as s weet corn mature s as chlorophyll is being degraded (Eskin, 1989).

The $\mathrm{b}^{*}$ values of SC1 and SC2 varieties were affected by harvest maturity at $P$ values of 0.01 and 0.05 , respectively while SM variety was not. This means that as harvest maturity increased, sweet corn kernel became more yellow in color. Those harvested at 20 and 22 DAS were found to be more yellow in color compared to the one harvested at 18 DAS. In the maturation of fruits and some vegetables, change in color was very much evident. As sweet corn carotenoid is synthesized, chlorophyll is lost (Eskin, 1989). As the vegetables remain intact with the parent plant, carotenogenesis continue to occur (Rod griguez-Amaya, 1997).

Chroma (saturation or vividness) is known to be dependent on $\mathrm{b} *$ value (yellowness). Chroma values of SC2 variety were significantly affected by harvest maturity at $P$ value $=0.01$. Harvest at 22DAS, which has the highest value among three harvest maturities, was significantly different fromharvest 18 and 20 DAS. Study done by Ugur and Maden(2015) showed that the cultiv ation period, varieties, and cultivation type of s weet corn have an effect statis tically on kernel chroma values. Sweet corn varieties' chroma values varied ranged from64.37-74.71 which is of greater value compared to what was obtained from this study. The saturation color decreased as the kernel matured. This contradicted the result of the study wherein no significant difference in the chroma values were observed with SC1 and SC3 while there was an increasing chroma values for SC2.

On the other hand, hue value is the indication of color change between yellow and red (Ugur and Maden, 2015). Hue value increased (red hue) with delayed sowing and planting time in sweet corn. Considering the maturation period, hue values were found higher as a result of the increase of starch in outer shell color. Once again the results of study done by Ugur and Maden (2015) was not of the s ame case with this study wherein the hue values of the three varieties were found to be not significantly different with harvest maturity and storage period regardless of the variety. On the other hand, in the study done by Alan (2014) u sing different varieties of sweet corn, it was reported that in the first year of the experiment there was no significant differences in the kernel hue values. However on the 2nd year of study, hue values were significantly affected by variety $(P<0.05)$.

\subsection{Proximate Composition of shrunken 2 sweet corn}

Table 2: Proximate composition of three varieties, percent dry weight basis

\begin{tabular}{|c|c|c|c|c|c|c|c|c|}
\hline VARIETY & HARVEST & $\% \mathrm{MC}$ & $\% \mathbf{A S H}$ & $\%$ PRO & \% FIBER & $\%$ FAT & $\%$ NFE & ENERGY \\
\hline \multirow[t]{3}{*}{ SC1 } & 18 & $76.08^{\mathrm{b}^{*}}$ & $3.40^{\mathrm{a}}$ & $11.87^{\mathrm{b}^{* *}}$ & $5.98^{a}$ & $5.13^{b^{*}}$ & $73.63^{a^{*}}$ & $92.84^{\mathrm{a}^{*}}$ \\
\hline & 20 & $73.88^{a^{*}}$ & $4.00^{\mathrm{a}}$ & $10.29^{a^{* *}}$ & $6.82^{\mathrm{a}}$ & $3.89^{a^{*}}$ & $75.00^{a^{*}}$ & $98.25^{b^{*}}$ \\
\hline & 22 & $74.32^{\mathrm{a}^{*}}$ & $3.55^{\mathrm{a}}$ & $10.58^{a^{* *}}$ & $5.10^{\mathrm{a}}$ & $3.79^{a^{*}}$ & $76.98^{b^{*}}$ & $98.72^{b^{*}}$ \\
\hline \multirow[t]{3}{*}{$\mathrm{SC2}$} & 18 & $78.90^{b^{*}}$ & $3.98^{\mathrm{a}}$ & $13.08^{a}$ & $5.76^{\mathrm{a}}$ & $3.20^{\mathrm{a}}$ & $73.98^{a}$ & $79.57^{a^{*}}$ \\
\hline & 20 & $76.55^{a^{*}}$ & $4.08^{\mathrm{a}}$ & $12.17^{\mathrm{a}}$ & $5.70^{a}$ & $5.78^{a}$ & $72.27^{\mathrm{a}}$ & $91.33^{b^{*}}$ \\
\hline & 22 & $75.60^{a^{*}}$ & $3.56^{\mathrm{a}}$ & $12.29^{\mathrm{a}}$ & $5.65^{\mathrm{a}}$ & $4.07^{\mathrm{a}}$ & $74.42^{\mathrm{a}}$ & $93.58^{b^{*}}$ \\
\hline \multirow[t]{3}{*}{ SC3 } & 18 & $73.54^{\mathrm{a}}$ & $3.08^{\mathrm{a}}$ & $10.53^{b^{* *}}$ & $3.42^{b^{* *}}$ & $3.42^{\mathrm{a}}$ & $77.51^{\mathrm{a}}$ & $79.57^{a^{* *}}$ \\
\hline & 20 & $74.25^{\mathrm{a}}$ & $3.71^{\mathrm{a}}$ & $11.24^{c^{* *}}$ & $4.15^{\mathrm{c}^{* *}}$ & $4.15^{\mathrm{a}}$ & $75.29^{a}$ & $91.33^{\mathrm{b}^{* * *}}$ \\
\hline & 22 & $74.05^{\mathrm{a}}$ & $3.06^{\mathrm{a}}$ & $11.27^{a^{* *}}$ & $2.49^{a^{* * *}}$ & $2.49^{\mathrm{a}}$ & $76.56^{\mathrm{a}}$ & $93.58^{c^{* * *}}$ \\
\hline
\end{tabular}

* Means are significantly different at $P<0.01$

** Means are significantly different at $P=0.01$

*** Means are significantly different at $P=0.05$

$\mathrm{NFE}$ - nitrogen free extract

The proximate analy ses of three varieties of s weet corn at different harvest maturity in dry bas is were summarized in Table 3.2.1. Huang and Fu (1992) (as cited by Cao et al., 2008) stated that as the seed develops, nutrients slowly accumulated inside the seeds and morphological and physiological changes happen until the seed reach maturation and high vig or. Percentage mois ture was significantly different with harvest maturity in SC1 and SC2 varieties with decreasing trend from $76.08 \%$ to $74.32 \%$ and $78.90 \%$ to $75.60 \%$, respectively. For both varieties, harvested sweet corn at 18 DAS, 
was significantly differentfrom 20 and 22DAS. Sweet corn harvested at 18DAS had higher percentage mois ture, $76.08 \%$, $78.90 \%$ and $73.54 \%$ for varieties SC1, SC2 and SC3, respectively. It continued to decrease as harvest period was delayed. Similarly, in a study done by Campbell and Mckerlie (1967), the moisture content of sweet corn decreased as theharvest season advanced. As sweet corn ripens, there was a decrease in kernel turgor as the consistency of parenchyma walls change. This caused the decrease in moisture content of s weet corn (Szymaneket al., 2006). On the other hand moisture content of sweet corn was an acceptable standard index of maturity while its value is associated with other indices (Campbell and McKerlie, 1967). Ols on (2000) reported that moisture percentage was correlated very closely to postharvest grade evaluation of sweet corn (as cited by Szymanek, 2009). It was also noted that there was a decrease in moisture content with maturation that consequently resulted to less tender and juicy pericarp (Ugur and Maden, 2015). The \% moisture of SC3 was not significantly different with maturity and had the lowest value among the three varieties for all harvest dates except at 20 DAS. Moisture content of $\operatorname{sh} 2 \mathrm{~s}$ weet corn upon harvest ranged from $76 \%$ to $79 \%$. It loses about $0.25 \%$ moisture per day at the optimum level (Matz, 1991). It was reported that the conversion of sugars into starch was also related to decreasing mois ture content of the kernels (Szymanek, 2009). In a study done by Wong (1994), sh2 s weet corns harvested at 20 days after pollination had varied mois ture content thereby highly suggesting that different hybrids had different rates of ear maturation. Among the studied sh2 hybrids (Wong et al., 1994), kernel moisture content also decreased as harvest period was delayed, from 5.2\% (20 DAP) to $0.6 \%$ per day (29 DAP). Similarly, results of this study showed consis tent decreased in percent mois ture content as harvest maturity increased.

Percent ash content of the three varieties were not significantly different with harvest maturity. Percent ash content ranged from $0.81 \%$ to $1.71 \%$ in all varieties of different maturity. Result agreed with Jalal(2003) as cited by Ullah et al., (2010) that the range of $0.7 \%$ to $1.3 \%$ were range for ash content of different corn. The ash content were found to decline as the grain matured (Sanderson et al., 1979). Although this was not true with the result of this study as harvest maturity did not have an effect with the ash content. Evers in 2001 (as cited by Ullah et al., 2010) reported that the grains with highest ash were known to contain greater amount of non-endosperm material. Ash values were analyzed to determine level of non-end osperm components present. Endosperms tored the carbohy drates of sweet corn. Decrease in endosperm size result in smaller, lighter kernels (Goldman and Tracy, 1994). Sh2 s weet corns in this study harvested at threeharvest maturities had insignificant difference in ash values thus non-endosperm content were the same regardless of harvest maturity. Percentage fiber of $\mathrm{SC} 1$ and $\mathrm{SC} 1$ were not affected by harvest maturity while $\mathrm{SC} 1$ had a significant decreased in fiber content as the plant matures. The fiber components of s weet corn were hemicellulose, cellulose and lignin (Johari and Kaushik, 2016).

Percent protein is the second largest chemical component of the kernel. Percent protein content is found in the range of 10.29-13.08\%. Sweet corn kernels contain albumins, g lobulins, prolamins and glutelins. While the embryo contains the globulin and endosperm, the major site for protein storage (Ullah et al., 2010). Percent protein content was significantly different $(\mathrm{P}<0.01)$ with harvest maturity in $\mathrm{SC} 1$ and $\mathrm{SC} 3$ varieties with $\mathrm{P}$ value $<0.01$ and $\mathrm{P}$ value $=0.05$, respectively while it was not significant with SC2. In SC1, percent protein at 18 DAS had the highest percentage protein value while SC3 harvested at 18DAS had the lowest value. As the s weet corn ripens, the protein content decreases fromthe surface of the kernel toward its center. Protein increases until the waxripeness phase then it progressively decreases. The proximate composition of various cultiv ars and various degree of ripeness are variable (Szymaneket al., 2006). Experiment done by Alan et al., (2014) shows that the protein content of sweet corn planted at the first year of the study is affected significantly $(\mathrm{P}<0.01)$ by variety only while at second year of the study the effects of variety and treatment variety interaction on protein content were found significant $(\mathrm{P}<0.01)$. Also the average results over the two years fresh, frozen and canned s weet com kernels had similar protein contents. It has been reported that sweet corn is one of the most important sources of dietary protein among vegetables because of its relatively high protein concentration $(3.5 \mathrm{~g} / 100 \mathrm{~g}$ edible portion) (Goldman and Tracy, 1994). Protein content results from th is study were $2.75,2.86$, and $2.87 \mathrm{~g} / 100 \mathrm{~g}$ edible portion for variety SC1, SC2 and SC3 respectively are slightly lower than what Goldman and Tracy reported.

Nitrogen free extract (NFE) is primarily composed of sugars, starch, phytoglycogen, and hemicellulose. Percent NFE shows consistent increase in values in SC1 variety as it matured from $73.63 \%$ to $76.98 \%$ while for variety SC2 and SC3, values were variable. Significant increase in NFE is only evident in SC1 variety wherein sweet corn harvested at 22 DAS had significantly highest value. It is similar with the results of study done by Szymanek et al. (2015) in which sh 2 harvested at different maturities shows increasing carbohydrates values harv ested at 3rd stage of maturity having the highest amount. Similarly, study done by Dodson and Tracy (2013) suggested that harvest dates were significant for moisture content and other components. It was als o found out that genotypes significantly affect the mois ture and carbohydrate content of sh2 sweet corn (Dodson and Tracy, 2013). As Szymaneket al. (2015) reported that there were significant difference between genotypes, and stage of maturity for carbohydrates, and mois ture concentration while carbohydrates per kernel were equal between cultiv ars. Variation in the concentrations of individual and total sugars is significant among the sh2 hybrids during one season of study done by Szyamanek in 2015. While increased in harvest maturity affected the changes in moisture, sugar and starch concentrations where decreased in moisture and sugars led to increase in the starch concentrations (Szymanek et al., 2015). This range of inconsistency among the sh2 hybrids indicates that allelic variation at other loci is affecting sucrose and total sugar levels in freshly harvested sweetcorn (Wong et al., 1994). 
Compared to othercereals, sweet corn is comparatively rich in oil for $90 \%$ is deposited in the germ(Szymanek et al., 2006). Percent fat content of s weet corn ranges from $2.49 \%$ to $5.78 \%$ in all varieties in different maturities. SC1 percent fat content were found to be significantly different $(\mathrm{P}<0.01 \%)$ with harvest maturity harvest at 22 DAS with the lowest values. There is a decrease in fat content as the sweet corn matures. Eskin (1989) reported that the genotype of s weet com dictates the oil content and composition. Sweet corn is a good source of polyunsaturated fatty acids. Lipid fractions tend to increase at day 23 to 29 after pollination (Es kin, 1989). On the other hand, the primary fatty acids present in sweet com are palmitic, stearic, oleic, linoleic and linoleic (Eskin, 1989). Sweet corn with high oil content has larger germsize and tend to have higher protein levels of protein (Weber, 1978). Contrary to the result of the study, Dagla et al. (2015) reported that there was a medium positive association with oil content and harvest maturity. Increasing harvest maturity also increased oil content in grains.

Mean energy content were significantly different with harvest maturity in all three varieties at $\mathrm{P} v$ alue $<0.01$ ( $\mathrm{SC} 1$ and $\mathrm{SC} 2$ ) and $\mathrm{P}=0.05$ (SC3). There was an increasing trend in mean energy content as maturity increased. This can be attributed to decrease in mois ture content leading to concentration and therefore increase in proximate composition. The difference in the energy level was due to differences in the proximate composition of the varieties. Results showed that these varieties of sweetcorn are rich source of energy.

\section{CONCLUSION}

Harvest maturity affected the sweet corn quality. As s weet corn matures there was a significant increase in length of $\mathrm{SC} 1$ and SC2. On the other hand all varieties ear diameter increased with maturity. The three varieties have significant difference in ear length and diameter. This implies that varietal differences play a role in ear leng th and diameter affecting the marketability and acceptability of the three varieties of shrunken- $2 \mathrm{~s}$ weet corn.

Lightness of kernels is not affected by maturity and varietal differences. Increasing $a^{*}$ and $b *$ values in suggest that the kernels become more red and yellow as they mature in the plant and this can be due to carotenogenesis. The $\mathrm{a}^{*}$ and $\mathrm{b}^{*}$ values of SC1 and SC2 were significantly affected by maturity while SC3 was not. In terms of chroma, only SC2 was significantly affected by harvestmaturity, with an increased in color vividness as it matures in the plant. While hue value of the three varieties was not affected by harvest maturity.

Percentage mois ture was significantly different with harvest maturity for $\mathrm{SC} 1$ and $\mathrm{SC} 2$ varieties with decreasing trend. For both varieties, harvested sweet corn at $18 \mathrm{DAS}$, is significantly different from 20 and $22 \mathrm{DAS}$. Sweet corn at $18 \mathrm{DAS}$ has higher mois ture content. The percentage mois ture of SC3 is not significantly different with harvest maturity and has the lowest value among the three varieties for all harvest dates except at 20DAS. Percent ash content of the three varieties are not significantly different with harvest maturity. Percent protein content is significantly different with harvest maturity in $\mathrm{SC} 1$ and $\mathrm{SC} 3$ varieties while it is not significant with variety SC2. It decreases as the sweet corn matures in the plant. For SC1, percent protein at 18DAS is significantly higher than at 20 and 22 DAS while it is higher at 22 DAS with SC3. Percent nitrogen free extract shows consistent increase in values $\mathrm{SC} 1$ variety as it matures while for variety $\mathrm{SC} 2$ and $\mathrm{SC} 3$, values are variable. Varieties $\mathrm{SC} 1$ and $\mathrm{SC} 3$ percent fat content are found to be significantly different with harvest maturity harvest at $22 \mathrm{DAS}$ with the lowest values. There is a decrease in fat content as the s weet corn matures. Las tly, there is an increasing trend in mean energy content as maturity increases.

From the conclusions mentioned, harvest maturity and varietal differences affect the physical and proximate composition of the three commercial varieties of shrunken $2 \mathrm{~s}$ weet corn in the Philippines. Understanding physicochemical characteristics and proximate compositions of commercially available sh $2 \mathrm{sweet}$ corn will allow producers, farmers and food processors in development of post-harvest methods and possibility of value added processing of $\mathrm{s}$ weet corn.

\section{REFERENCES}

[1] Alan, O., Kinaci, G., Kinaci, E., Budak Bascift, Z., Sonmez, K., Evrenosoglu, Y., \& Kutlu, I. 2014. Kernel Quality of Some Sweet Corn Varieties in Relation to Proces sing. Notulae Botanicae Horti Agrobotanici 42:414-419.

[1] Anderson, J., Paulis, J., Porcuna, F., \& W all, J. 1979. Sweet Corn: Varietal and Developmental Difference Amino Acid Content and Composition of Grain. Journal of Food Science 44:836-838.

[1] Campbell, J. D. \& Mckerlie, E. M. 1967. The Evaluation of Methods to Determine Sweet Corn Maturity for Processing. Canadian Journal of Plant Science 47:381-387.

[1] Cao, D., Hu, Jhuang, X., Wang, J., Guan, Y., \& Wang, Z. 2008. Relationships between changes of kernel nutritive components and seed vigor during development stages of $\mathrm{F} 1$ seeds of $\mathrm{sh} 2 \mathrm{sweet}$ corn. Journal of Zhejiang University Science B 9:964-968. 137-138 pp. 
[1] Dagla, M., Gadag, R., O P , S., \& Kumar, N. 2015. Genetic variability and correlation among yield and quality traits in sweetcorn. Electronic Journal of Plant Breeding 6:500-505.

[2] Dodson, H. G., \& Tracy, W. F. (2013). Endosperm Carbohydrate Composition and Kernel Characteristics of shrunken2-intermediate (sh2-i/sh2-i Su 1/Su1) and shrunken2-intermediate-sugary1-reference (sh2-i/sh2-i su 1-r/su 1-r) in Sweet Corn. PhD Dis sertation. The University of Wisconsin Madison.1-8 pp.

[2] Eskin, M. (1989). Quality and preservation ofvegetables. Florida, United States: CRC Press.

[1] Goldman, I., \& Tracy, W. 1994. KernelProtein Concentration in sugary-1 and shrunken-2 Sweet Corn. Hort Science 29:209-210.

[1] Johari, Aanchal \& Kaushik, Isha. 2016. Sweet corn: New Age Health Food. International Journal ofRecent Scientific Research.7:12804-12807.

[2] Jugenheimer, R. (1976). Corn; Improvement, Seed Production and Uses. New York: John Wiley \& Sons, Inc.

[2] Markovic, I., Ilic, J., Markovic, D., Simonovic , V., \& Kosanic, N. n.d. Color Measurement of Food Products Using CIE L*a*b* and RGB. Journal of Hygienic Engineering and Design 4:50-53.

[2] Rodríguez, G. R., Moyseenko, J. B., Robbins, M. D., Huarachi Morejón, N., Francis, D. M., Van Der Knaap, E. (2010). Tomato Analyzer: A Us eful Software Application to Collect Accurate and Detailed Morphological and Colorimetric Data from Two-dimensional Objects.J. Vis. Exp. 37, e1856, doi:10.3791/1856.

[1] Szymanek, M. 2009. Influence of Sweet Corn Harvest Date on Kernels Quality.Research in Agricultural Engineering 55 pp. 10-17.

[2] Szymanek, M., Dobrzañski Jr., B., Rybczyñski, R., \& Niedziolka, I. (2006). Sweet Corn Harvest and Technology: Physical Properties and Qualities (1 st ed.). B. Dobrzañski Institute of Agrophysics Polish Academy of Sciences, pp. 2530.

[1] Ullah, I., Ali, M., \& Farooqi, A. 2010. Chemical and Nutritional Properties of Some Maize (Zea mays L.) Varieties Grown in NWFP, Pakistan. Pakistan JournalofNutrition, 9pp. 1113-117.

[1] Ugur, A., \& Maden, H. 2015. Sowing and Planting Period on Yield and Ear Quality of Sweet Corn (Zea mays L. var. saccharata). Science and Agrotecnologia 39:48-57.

[1] Wong, A., Juvik, J., Breeden, D., \& Swi, J. 1994. Shrunken2 Sweet Corn Yield and the Chemical Components of Quality. Journal of the American Society of Horticultural Science. 119:747-755. 